University of Michigan Law School

University of Michigan Law School Scholarship Repository

Law \& Economics Working Papers

$5-3-2017$

\title{
Lead Plaintiffs and Their Lawyers: Mission Accomplished, or More to Be Done?
}

\author{
Adam C. Pritchard \\ University of Michigan Law School, acplaw@umich.edu \\ Stephen Choi \\ NYU Law School, stephen.choi@nyu.edu
}

Follow this and additional works at: https://repository.law.umich.edu/law_econ_current

Part of the Law and Economics Commons, Litigation Commons, and the Securities Law Commons

\section{Working Paper Citation}

Pritchard, Adam C. and Choi, Stephen, "Lead Plaintiffs and Their Lawyers: Mission Accomplished, or More to Be Done?" (2017). Law \& Economics Working Papers. 130.

https://repository.law.umich.edu/law_econ_current/130

This Article is brought to you for free and open access by University of Michigan Law School Scholarship Repository. It has been accepted for inclusion in Law \& Economics Working Papers by an authorized administrator of University of Michigan Law School Scholarship Repository. For more information, please contact mlaw.repository@umich.edu. 


\title{
NEW YORK UNIVERSITY SCHOOL OF LAW NYU Center for Law, Economics and Organization
}

\author{
Lead Plaintiffs and Their Lawyers: Mission Accomplished, \\ or More to Be Done?
}

Stephen J. Choi and A.C. Pritchard

May 2017

\section{LAW \& ECONOMICS RESEARCH PAPER SERIES WORKING PAPER NO. 17-11}




\title{
Lead Plaintiffs and Their Lawyers: Mission Accomplished, or More to Be Done?
}

\author{
Stephen J. Choi \& A.C. Pritchard* \\ DRAFT: May 2017, forthcoming RESEARCH HANDBOOK ON SHAREHOLDER LITIGATION (Jessica Erickson, \\ Sean Griffith, Verity Winship, David Webber, eds., forthcoming 2017)

\section{Introduction}

More than twenty years ago, Congress adopted the Private Securities Litigation Reform Act (PSLRA) 1 in response to widespread claims of frivolous securities fraud litigation. The PSLRA contains a variety of provisions designed to limit litigation and to reduce the settlement value of non-meritorious or nuisance claims. These provisions include a heightened pleading requirement, 2 a safe harbor from liability for forward-looking statements, 3 a requirement that plaintiffs prove loss causation, 4 a mandatory discovery stay pending a motion to dismiss, 5 and the replacement of joint and several liability with proportionate liability for collateral defendants. 6 There is evidence that these reforms strengthened the connection between the merits and the outcomes in securities fraud class actions (Johnson, Nelson \& Pritchard, 2007).7 It is still the case, however, that a substantial percentage of claims - more than half - are dismissed or settled for nuisance value.

A second-and ostensibly independent-goal of the PSLRA was to "empower investors so that they, not their lawyers, control securities litigation." 8 Congress believed that individual investors who served as class representatives prior to the enactment of the PSLRA were largely figureheads dominated by class action lawyers. As one prominent (now disbarred and a felon) plaintiff' attorney famously said, "I have the greatest practice of law in the world. ... I have no clients." (Barrett 1993) Because class action lawyers typically had a much greater interest in the class

\footnotetext{
* Choi is Murray and Kathleen Bring Professor, New York University Law School; Pritchard is Frances and George Skestos Professor, University of Michigan Law School. This is a draft chapter that has been accepted for publication by Edward Elgar Publishing in the book Research Handbook on Representative Stockholder Litigation (Jessica Erickson et al., eds. forthcoming 2017). We would like to thank Sean Griffith and other participants at the Fourth Annual Workshop for Corporate \& Securities Litigation for helpful comments on an earlier draft of this article. Pritchard acknowledges the generous support of the William W. Cook Endowment of the University of Michigan.

1 Pub. L. No. 104067, 109 Stat. 737 (1995) (codified at 15 U.S.C. §§ 77a et seq.).

2 See Section $21 \mathrm{D}(\mathrm{b})(2)$, Exchange Act.

3 See Section 27A, Securities Act; Section 21E, Exchange Act

4 See Section 21D(b)(4), Exchange Act.

5 See Section 27(b), Securities Act; Section 21D(b)(3)(B), Exchange Act.

6 See Section 21D(f), Exchange Act. Outside directors also enjoy proportionate liability under Section 11 of the Securities Act. See Section 11(f)(2), Securities Act.

7 But see Choi (2007) (providing evidence that the reforms reduced the incidence of certain types of meritorious claims).

8 S. Rep. No. 104-98 (1995); see also H.R. Conf. Rep. No. 104-369, at 32 (1995).
} 


\section{Choi \& Pritchard, Lead Plaintiffs}

recovery than the named class representatives, plaintiffs may have lacked the incentive to monitor class counsel. (Coffee, 1986). To remedy that imbalance, the PSLRA created a presumption that courts should appoint as lead plaintiff the class member seeking appointment with the largest financial interest in the relief sought.9 The provision vests the lead plaintiff with authority to select and retain class counsel.

Large shareholders, the theory went, would have more of an incentive to oversee lawyers who represent the class. Congress hoped that institutional shareholders serving as lead plaintiffs would negotiate with class counsel over attorneys' fees, ensuring that a larger share of the recovery would accrue to the class members. In addition, an active shareholder-monitor would discourage class action counsel from settling good cases on the cheap.

We now have more than twenty years of litigation experience since PSLRA was adopted-enough time to assess the statute's effects, tallying up what has been accomplished and highlighting where further reforms might be needed. In substantial measure, the PSLRA's lead plaintiff provision has succeeded. After a slow beginning, institutional investors have stepped forward to serve as lead plaintiffs in a substantial number of cases. As we discuss below, there is evidence that institutional investors are more likely to volunteer as lead plaintiffs in the strongest cases, and that they may play a role in ensuring greater recovery for investors in those cases. In addition, institutional investors seem to have reduced the share of recovery that goes to pay lawyers postPSLRA. In sum, the PSLRA has changed the game for securities class action lawyers, who now compete for the favor of institutional investors in order to be selected as counsel.

There is also evidence, however, that that competition has not been driven exclusively by price and quality of representation. The larger institutional investors that have most frequently agreed to serve as lead plaintiffs in securities class actions have been government-sponsored pension funds. Many of these funds are managed directly by politicians, such as state comptrollers, who must campaign to retain their current positions, or may have designs on higher offices. Alternatively, these funds are managed by political appointees, who typically owe their position to the state's governor. The political influence over these funds raises the question whether law firms are making campaign contributions to politicians to enhance their chances of being selected to represent the funds. The available evidence raises suspicion that at least some class action law firms are buying lead counsel status with campaign contributions, i.e., lawyers are paying to play. Not surprisingly, government officials receiving campaign contributions appear to be less vigorous overseers of class action counsel.

In this chapter, we assess what we know about lead plaintiffs and their lawyers and what reforms might enhance the role played by lead plaintiffs in securities class actions. In Part I, we provide background on the lead plaintiff provision and how it operates. In Part II, we survey the existing literature on the effects of the lead plaintiff provision. In Part III, we build off that understanding to explore potential reforms relating to lead plaintiffs and their lawyers. In particular, we suggest specific reforms that might promote additional transparency and competition on price, rather

9 Private Securities Litigation Reform Act of 1995 § 101(a), 15 U.S.C. § 77z-1(a)(3)(B) (2006). 
than buying political favor. More provocatively, we suggest additional requirements for lead plaintiffs to further enhance the screening role played by the PSLRA.

\section{Background and purposes of the PSLRA}

The PSLRA was Congress's response to widespread calls for reform of securities fraud litigation. The statute was enacted following an extensive lobbying campaign by accounting firms, corporate leaders and members of the securities industry, who complained that plaintiffs' lawyers were filing excessive and frivolous cookie-cutter complaints, often on the basis of no more than a sudden drop in stock price, in an effort to coerce nuisance settlements. Critics described meritless lawsuits as "blackmail," forcing "innocent" firms to settle rather than endure the high costs of vindicating themselves through litigation. (Saparoff, 1996).

Congress' perception that securities fraud class actions were "lawyer-driven litigation" was a separate, although related, concern.10 Congress heard testimony that lawyers maintained rosters of professional plaintiffs, willing to file suit at the lawyer's request. Class representatives seemed to have little involvement in litigation decisions, and even less control. Perhaps most important, lawsuits outcomes appeared to favor the interests of class counsel over the class itself - generally resulting in substantial fee awards, but often providing limited compensation to class members.11

One of the abuses of securities class actions that Congress attempted to address in enacting the PSLRA was "the manipulation by class action lawyers of the clients whom they purportedly represent." 12 Congress found a potential solution to that problem in a proposal by Weiss and Beckerman (1995). Weiss and Beckerman argued that institutional investors, if placed in the lead plaintiff role, would act as effective monitors of plaintiffs' attorneys' actions in securities class action litigation. Acting on their proposal, Congress adopted the PSLRA's lead plaintiff provision, which creates a "rebuttable presumption . . . that the most adequate plaintiff . . . is the person or group of persons that ... has the largest financial interest in the relief sought by the class." 13 The PSLRA also stated that the most adequate plaintiff will "select and retain counsel to represent the class."14 The premise of the PSLRA's lead plaintiff provision is that larger investors, with correspondingly larger stakes in the class recovery, would serve as more effective monitors of class counsel. By providing effective monitoring, the lead plaintiff would protect the interests of the absent class members.

Congress worried, however, about the potential for lead plaintiff monitoring to be undermined by side payments, leading Congress to include a provision in the PSLRA prohibiting non pro-rata

\footnotetext{
10 The Common Sense Legal Reforms Act, H.R. 10, 104 ${ }^{\text {th }}$ Con. $1^{\text {st }}$ Sess. $\S 202$ (1995) (provision entitled "Prevention of Lawyer-Driven Litigation").

11 See, e.g., H.R. Conf. Rep. No. 104-369, at 36 (1995), reprinted in 1995 U.S.C.C.A.N. 730 (observing that lawyers "often receive a disproportionate share of settlement awards"); Sen. Rep. No. 104-98 at 9 (complaining that, although investors recover only "pennies on the dollar," much of the $\$ 1.4$ billion paid during 1994 alone went to plaintiff s' lawyers).

12 See H.R. Rep. No. 369, at 31 (1995), reprinted in 1996 U.S.C.C.A.N. 730, 1103.

1315 U.S.C. § 78u-4(a)(3)(B)(iii)(I).

1415 U.S.C. $\S 78 u-4(a)(3)(B)(v)$.
} 


\section{Choi \& Pritchard, Lead Plaintiffs}

payments to the lead plaintiff.15 Such payments were rumored to have been an issue in securities class actions prior to the adoption of the PSLRA. (Those rumors appear to have been well founded; several former partners of the Milberg Weiss law firm, now "Milberg," subsequently went to prison for hiding such payments from courts overseeing securities class actions (Selvin 2008).) Those payments raised concerns that class representatives would not have an incentive to protect the interests of absent class members. One measure of lead plaintiff monitoring is attorneys' fees; vigilant monitors presumably would negotiate lower fees, which would mean a greater net recovery for class members. Consistent with this theory, Perino (2008) finds that Milberg Weiss's attorneys' fees were significantly higher for cases in which side payments were made to lead plaintiffs (as identified in the indictment against the firm) than in those cases in which payments were not made.

\section{Effects of the Lead Plaintiff Provision}

\section{A. Who Are the Lead Plaintiffs?}

The lead plaintiff provision took time to get rolling. The number of institutions participating as lead plaintiffs was quite small in the first few years following the adoption of the PSLRA. In a report on the first year of practice under the PSLRA, the SEC reported that institutional investors became lead plaintiffs in only eight of 105 filed cases (SEC, 1997). This indifference was overcome relatively quickly, however, with institutional investors stepping forward as lead plaintiffs in substantial numbers of securities fraud class actions. A 2003 study released by Cornerstone Research reported that institutions had served as lead plaintiffs in approximately $30 \%$ of postPSLRA cases, a figure that Cornerstone described as a substantial increase from the pre-PSLRA participation rate of $15 \%$ (Simmons \& Ryan, 2003). A PricewaterhouseCoopers study (2003) reported that institutional investors represented $51 \%$ and $42 \%$ of lead plaintiffs, respectively, in all securities class actions filed in 2002 and 2003. These institutional investors were producing results; Choi, Johnson-Skinner and Pritchard (2011) report that at least one institution was the lead plaintiff in 58.9\% of class actions filed from 2002 to mid-2007 that resulted in a settlement. It is fair to say that for more than a decade, institutional investors have dominated as lead plaintiffs. Their presence is particularly felt in the largest cases, which tend to attract multiple class members stepping forward seeking to serve as lead plaintiff.

What explains this increase in institutional participation? One factor is greater experience under the PSLRA. As courts converged in their interpretation of the lead plaintiff provision and institutions become more experienced with the lead plaintiff role, the perceived benefits of participation began to outweigh the potential costs in a given case. A second factor is the evolving judicial preference for a single institutional lead plaintiff over a large group of individuals. Courts in some early post-PSLRA cases appeared to endorse the idea that plaintiffs' lawyers could cobble together large groups of lead plaintiffs and aggregate their losses (Fisch, 2001). The more plaintiffs a lawyer could attract, the better her chances of winning the contest of having the

1515 U.S.C. $\S 78 u-4(a)(4)$. 
largest collective stake in the case. The rise in institutional lead plaintiffs suggests that courts have become more skeptical of this practice.

Although the studies show overall increased institutional participation, the increase does not appear to have been uniform across types of institution. Public pension funds appear to have been considerably more active than other institutions. Most notably, certain types of institutional investors, such as mutual funds, have not in participated securities fraud litigation in meaningful numbers, despite their substantial holdings.

There are two potential explanations for the failure of mutual funds to participate as lead plaintiffs. The first is the standard agency problem. Litigation decisions are made by mutual fund managers, who are evaluated on the basis of fund performance relative to other funds and market benchmarks. Litigation recoveries do not go to fund managers, but to fund beneficiaries. Because of the time lag between the fund's trading and the resolution of litigation, litigation recoveries may not be fully reflected in performance figures. At the same time, a mutual fund's participation as lead plaintiff would draw public attention to the fact that the fund has been the victim of fraud, perhaps reflecting adversely on the expertise of the fund's managers. The second explanation is that a substantial component of business for the major mutual funds involves managing retirement accounts for publicly traded issuers. Unlike litigation recoveries, the fees associated with these services go directly to mutual fund managers. Fund managers might reasonably be concerned that active litigation participation would hurt their ability to compete for this business from managers of public companies.

When one examines participation by institutions other than public pension funds, such as hedge funds, private pension funds, and trusts, the nature and effect of institutional participation becomes murky. It can be difficult, particularly with some smaller investors to determine whether they should be classified as institutions or individuals. Importantly, these other institutions differ substantially from each other and from the large public pension fund or mutual fund that Weiss and Beckerman (and Congress) projected as the prototypical institutional lead plaintiff. These differences may go to the issue of whether the institutions are capable of responsibly serving as lead plaintiffs. Weiss and Beckerman assumed, with little discussion, that institutions will be typical and adequate representatives of other class members. Accordingly, Weiss and Beckerman devoted relatively little attention to exploring the ways in which institutional investors' interests might diverge from those of the rest of the class. Similarly, Weiss and Beckerman focused on the institutional investor as a singular entity, ignoring agency problems among actors within an institution that might impede its ability to act in the interests of its own beneficiaries (and other members of the class). This concern manifests itself most acutely in the form of pay to play. We focus more on this issue below.

Hedge funds reflect a distinct group of institutional investors that have the potential to play a meaningful role in securities litigation. Hedge funds are typically sophisticated investors, and due to their investing strategies, often have substantial stakes in their portfolio companies. The ability of hedge funds to hold concentrated interests rather than a diversified portfolio coupled with the metrics by which hedge fund performance is measured increase the likelihood that hedge fund managers will benefit from a litigation recovery relative to mutual fund managers. On the other 


\section{Choi \& Pritchard, Lead Plaintiffs}

hand, due to the distinctive trading strategies employed by hedge funds, these are the institutions most likely to face typicality objections to their taking the lead plaintiff position. Although hedge funds have participated as lead plaintiffs post-PSLRA, they have not become dominant players.

Much more common as lead plaintiffs-but less promising-are union pension funds. Although these funds typically have greater funds under investment than the average individual, it is doubtful that their investment sophistication measures up to that of larger institutions. Moreover, their ability to act as independent monitors of class counsel is open to serious question, given the recruitment efforts used by plaintiffs' lawyers to attract them.

An additional factor that may impair institutional oversight is the structure of institutional participation. Prior to the adoption of the PSLRA, many institutions were part of what was effectively a group of plaintiffs that also included a number of individual investors. Courts initially disagreed on whether groups should be appointed as lead plaintiffs under the PSLRA.16 Despite several decisions criticizing the appointment of unrelated investors as a lead plaintiff group, courts continue to appoint institutional investors, particularly smaller institutions as co-lead plaintiffs together with one or more individual investors.17 In some post-PSLRA cases, courts have appointed groups of public pension funds to serve as lead plaintiff.

The potential effectiveness of institutional participation may be reduced when an institution serves as a member of a mixed lead plaintiff group. Courts and commentators that have criticized the use of lead plaintiffs groups argue that such groups are often formed by counsel and as a result do not exert the type of control over lawyers that was the objective of the PSLRA.18 If this is true, institutional participation as part of a group may not be as effective in monitoring counsel, and such groups will not have a significant effect on fee awards or fee structures. Moreover, the appointment of a lead plaintiff group can lead to a fractured position among group members or cause some members to refrain from active participation.19

\section{B. What Is the Effect of Institutional Lead Plaintiffs?}

${ }_{16}$ Compare In re Telxon Corp. Sec. Litig., 67 F. Supp. 2d 803, 811-16 (N.D. Ohio 1999) (rejecting the argument that a lead plaintiff should consist of a group of unrelated investors) with In re Cendant Corp. Litig., 264 F.3d 201, 267 (3d Cir. 2001) (holding that "rule of reason" should be applied to determine whether size and nature of group appointment is appropriate). See also Brief of the Securities and Exchange Commission as Amicus Curiae in Support of Appellants on the Issues Specified. In re Cendant Corp. Litig., Nos. 00-2769, 00-3653, 264 F.3d 201 (3d Cir.), at 17 $\mathrm{n} .13$ (endorsing concept of lead plaintiff group but arguing that group should consist of no more than five members). 17 See, e.g., Tice v. Novastar Fin., Inc., 2004 U.S. Dist. LEXIS 16800, *29 (W.D. Mo. 2004) (appointing institution and two individuals to "ensure a broader, more diverse representation of the class"); In re Party City Litigation, 189 F.R.D. 91, 114 (D.N.J. 1999) (appointing individual and institutional investors as co-lead plaintiffs); In re Oxford Health Plans, Inc. Sec. Litig., 182 F.R.D. 42, 47-49 (S.D.N.Y. 1998) (explicitly endorsing joint appointment of institution and several individuals on the basis that it would result in "diverse representation).

18 See, e.g., Telxon, at 811-16 (stating that appointed of unrelated groups would thwart legislative purpose of greater client control).

19 See, e.g., Kloster v. McColl (In re BankAmerica Corp. Secs. Litig.), 350 F.3d 747 (8th Cir. 2004) (describing inability of lead plaintiff group to agree on whether to approve or object to proposed settlement and failure of some group members even to take a position). 


\section{Settlement Amounts}

We now have considerable evidence that the PSLRA's lead plaintiff provision has led to improved monitoring of class counsel in a broad range of cases. Choi, Fisch, and Pritchard (2005) report that the presence of public pension funds correlates with high value settlements. That finding is not surprising, since they also find that institutional investors are more likely to serve as lead plaintiffs in cases with accounting restatements or SEC investigations-obvious indicia of merit. Simmons and Ryan (2005) and Cox and Thomas (2006) also report that institutional lead plaintiffs correlate with increased settlement amounts. Cox and Thomas (2006) also note, however, that the provable losses of individual lead plaintiffs are a trivial percentage of the claims filed in the cases in their sample, calling into question the incentives of individuals to monitor class counsel. Cox, Thomas, and Bai (2008) similarly report that institutional investor lead plaintiffs, in particular public pension funds and labor unions, are positively related to larger settlement amounts even when controlling for a measure of provable losses, market capitalization, class period length, and the presence of an SEC enforcement action. By contrast, they also find that very small settlements (less than \$3 million) are predominantly found in cases with individual lead plaintiffs. These studies suggest that institutional investors who serve as lead plaintiffs may be promoting larger recoveries for shareholder class members, relative to individual lead plaintiffs.

Cornerstone Research's latest settlement report offers a more comprehensive comparison of the settlements obtained by institutional and individual lead plaintiffs (Bulan, Ryan, \& Simmons, 2015). In 2015, 64\% of settled cases had an institutional investor as lead plaintiff. Cornerstone reports a median settlement amount of \$18 million for cases involving public pension fund as lead plaintiff. For other cases with an institutional investor as lead plaintiff (presumably primarily labor pension funds), the median settlement value was $\$ 6.4$ million, which is slightly greater than the overall median of $\$ 6.1$ million. For cases with an individual investor as lead plaintiff, the median settlement value was a paltry $\$ 2.7$ million, consistent with the finding of Cox, Thomas \& Bai (2008). This finding suggests that individuals serving as lead plaintiffs are primarily associated with nuisance-value settlements, and that institutional investors which are not public pension funds are not much better.

There is obviously a selection effect at work here. Cheng et al. (2010) report that suits brought by institutional investors are less likely to be dismissed, which is fairly direct evidence that the suits they choose to participate in have greater merit (to the extent the identity of lead plaintiff does not in and of itself affect the probability of dismissal). If public pension funds choose only to participate as lead plaintiff when the litigation involves large potential damages and a higher probability of recovery, higher settlements will naturally follow. This selection effect means that there may be a correlation between public pension funds' participation and larger settlement amounts, but it does not support an inference of a direct causal relationship. But selection may be just as important as the vigor with which these cases are litigated, as we discuss below.

\section{Attorneys' Fees}

Choi, Fisch, and Pritchard (2005) also examine the relationship of lead plaintiffs and attorneys' fees. They report no significant correlation between fees and public pension funds post- 


\section{Choi \& Pritchard, Lead Plaintiffs}

enactment once they control for the size of the case. Their study looked only at cases filed from 1991 to 2000, so it antedates the time that institutional investors stepped forward in large numbers to serve as lead plaintiff. Looking at a later sample period, Choi (2011) finds significantly lower fee requests-along with greater hours worked-for cases with institutional investors serving as lead plaintiffs. He also finds that lead plaintiffs with smaller provable losses are less likely to negotiate for lower attorneys' fees.

Perino (2012), after controlling for case quality, finds that cases with public pension lead plaintiffs have larger recoveries and lower fee requests and fee awards than cases with other lead plaintiff types. He also finds a spill-over effect: fee requests have declined generally over time, suggesting that lower fees negotiated by institutional investors have reduced the going rate in cases with individual investors serving as lead plaintiffs as well.

More recently, Baker, Perino, and Silver (2015) find that judges in districts with a high volume of securities litigation are more likely to cut fees, and fees are generally lower in high volume districts. More troubling, they also find that fee reductions are essentially random. Moreover, they find little evidence that lead plaintiffs are negotiating attorneys' fees agreements at the outset of the litigation, when their efforts are most likely to be effective. They conclude that courts are generally setting fees in securities fraud class actions the same way that they did before the enactment of the PSLRA: ex post, based on the results of the suit. They also suggest reforms to improve the process, which we discuss below.

\section{Pay To Play}

It is not all sunshine and roses with respect to public pension funds as lead plaintiffs. Media reports have highlighted political contributions to officials overseeing public pension funds who serve as lead counsel to the lead plaintiffs. For example, Fortune magazine ran a story detailing political contributions received by former New York State Comptroller Carl McCall from the partners at Bernstein, Litowitz, Berger \& Grossman (BLBG) (Weinberg \& Fisher 2004). McCall received these contributions shortly before McCall chose BLBG to serve as the New York public pension fund's counsel in the WorldCom securities class action, which produced one of the largest settlements ever in a securities class action - and a correspondingly large fee for BLBG.

McCall was also involved in perhaps the most frequently cited example of pay to play in securities cases, In re Cendant Corp. Litigation. The district court in Cendant discovered that two law firms selected as lead counsel contributed nearly $\$ 200,000$ to McCall, who was the sole director of the New York public pension fund that was a lead plaintiff in the case (Dewan 2002). The district court in Cendant, however, declined to find that pay to play affected the selection of counsel, and this finding was affirmed by the Court of Appeals for the Third Circuit.20 The Cendant court's skepticism that pay to play had an important influence on counsel selection is typical; a district court in California rebuffed "speculative" arguments that political contributions created a conflict

20 In re Cendant Corp. Litig., 264 F.3d 201, 269 (3d Cir. 2002). 
between the attorney and the class, noting that "[c]ourts have long been less enamored of securities litigation pay-to-play arguments than litigants and the press." 21

Johnson-Skinner (2009) provides the first systematic effort to document pay to play. He presents summary statistics of law firm political contributions side-by-side with pension funds' selection of law firms as counsel in securities class actions from 2002 to 2006 . He finds that law firms do contribute to the officials of funds that select them as class counsel in a substantial number of cases. By contrast, Webber (2010) rejects arguments that pay to play has a substantial influence on counsel selection based on his finding that the number of politicians on pension funds' board correlates negatively with selection as lead counsel. Unlike Johnson-Skinner, however, Webber does not examine the influence of campaign contributions, which would seem to be a more direct measure of the incidence of pay to play.

Choi, Johnson-Skinner, and Pritchard (2011) study the effect of campaign contributions to lead plaintiffs on the level of attorneys' fees in securities class actions. They find that state pension funds generally pay lower attorneys' fees when they serve as lead plaintiffs in securities class actions than do individual investors serving in that capacity, and larger funds negotiate for lower fees. This differential disappears, however, when they control for campaign contributions made to officials with influence over state pension funds. This effect is most pronounced for state pension funds that receive the largest campaign contributions and that associate repeatedly as lead plaintiff with a single plaintiffs' attorney firm. Thus, pay to play appears to increase agency costs borne by shareholders in securities class actions, undermining one of Congress's principal goals in adopting the Private Securities Litigation Reform Act. They do not, however, find any correlation between campaign contributions and weaker cases. It appears that plaintiffs' attorneys are only willing to invest in access to potential lead plaintiffs for cases in which there is likely to be competition to serve as lead counsel.

Other forms of recruitment of institutional lead plaintiffs have also persisted in the post-PSLRA era. These recruitment efforts are more difficult to document than campaign contributions, however, so they are less amenable to statistical analysis. Securities class action law firms provide "portfolio monitoring" services for institutional investors, alerting their clients to the possibility of legal claims for securities fraud. Not coincidentally, the law firm providing the monitoring services gets a leg up in the competition to represent the largest investors, a critical advantage in being appointed as counsel to represent the class in a securities fraud class action. Plaintiffs' law firms also sponsor conferences for pension fund managers, including managers of labor union pension funds; these conferences - typically held in warm, sunny places-appear to function as recruiting grounds for potential lead plaintiffs.

\section{Lead Plaintiff Reforms}

\section{A. Transparency}

21 In re Countrywide Fin. Corp. Sec. Litig., Case No. CV-07-05295 (C.D. Cal. Dec. 9, 2009). 


\section{Choi \& Pritchard, Lead Plaintiffs}

The evidence discussed above suggests that the lead plaintiff provision has promoted greater recovery for shareholders and reined in the percentage of that recovery that goes to plaintiffs' lawyers. These results are consistent with Congress's vision in enacting the lead plaintiff provision: institutional investors would take control of securities fraud class actions, aligning such suits more closely with the interests of shareholders generally. The evidence also suggests, however, that in certain circumstances plaintiffs' lawyers have successfully subverted the monitoring that Congress intended by making campaign contributions to key government officials who have influence over public pension funds. This section discusses reforms that could address these concerns by bringing increased transparency to securities litigation.

\section{Campaign Contributions}

To ensure that Congress's purposes are not undermined, courts need to take a closer-and earlier-look at the relationship between lead plaintiffs and their lawyers. Payments to plaintiffs in class actions other than their pro rata share of the recovery are already prohibited.22 The question is: Are those prohibitions being enforced? To ensure the alignment of interest between the lead plaintiff and the class that Congress intended is not subverted by pay to play, courts should take a hard look when a state and local pension fund comes forward to seek lead plaintiff status. If government officials affiliated with that fund have received political contributions from the firms representing them, those institutions should not be presumed to be the vigorous monitors that Congress hoped to attract when it adopted the lead plaintiff provisions of the PSLRA. Accordingly, courts appointing lead plaintiffs should inquire whether campaign contributions have been made after a firm has represented a pension fund in a class action that generated a settlement for the class. If contributions are being made as quid-pro-quo for selection as counsel, either explicitly, or more likely, implicitly, that would seem to violate the PSLRA's prohibition on non-pro rata recovery. Disclosure of such contributions at the time that the lead plaintiff was being selected would allow for disqualification of funds that have received pay-to-play at the outset. To ensure that the prohibition is effective, law firms seeking lead counsel status should be required to commit to not making campaign contributions to officials connected to state pension funds going forward as well.

\section{Repeat Plaintiffs}

The PSLRA bars shareholders from serving as a lead plaintiff in more than five securities class actions in any three-year period.23 That limit is easily circumvented, however. To start, the restriction may be ignored by a court at its discretion.24 In addition, individual state pension fund officials may control a number of different pension funds. Depending on the holdings of the particular funds, state officials may be able to skirt the PSLRA's limits by relying on different funds in different cases. Tightening these limits on repeat plaintiffs would curtail the ability of plaintiffs' attorneys to recruit lead plaintiffs through political contributions. Institutions seeking lead

\footnotetext{
2215 U.S.C. $\S 78 u-4(a)(4)$.

2315 U.S.C.A. $\S 78 v-4(a)(3)(v i)$.

24 See, e.g., Iron Workers Local No. 25 Pension Fund v. Credit-Based Asset Serv. and Securitization LLC, 616 F. Supp. 2d 461, 467 (S.D.N.Y. 2009).
} 
plaintiff status should be required to disclose not only their own involvement in prior cases, but also that of affiliated funds. This limit would require lawyers to justify their litigation decisions to a broader group of shareholders when soliciting clients to file suits.

\section{Fee Arrangements}

Transparency-and competition-would be further enhanced if investors seeking lead plaintiff status were required to publicly disclose their fee arrangements with their proposed lead counsel. Disclosure of fee agreements at the time that investors were seeking to be appointed lead plaintiff would provide tangible evidence - in the form of lower fees - that a prospective lead plaintiff was interested in promoting the interests of the investor class members, rather than the lawyers. Moreover, insofar as the PSLRA seeks to promote competition amongst lawyers for work in securities class actions, market forces cannot work effectively unless the market is transparent. Prices will find their own level only if those prices are available to all participants. Forcing proposed fee agreements out in the open, and discussing them in judicial opinions appointing lead plaintiffs will make prices clear for courts that do not see a high volume of these cases.

Baker, Perino, \& Silver (2015) offer a similar proposal, requiring courts to review fee arrangements at the outset of the litigation, but would allow proposed lead plaintiffs to submit their fee arrangements under seal to the court for in camera review. They point out that disclosing fee arrangements would reveal break points in counsel's compensation based on percentage of recovery. (Percentages typically decline as recoveries increase.) They worry that public disclosure would provide a strategic advantage to defendants, who might propose settlements targeting those break points, knowing that counsel would have a lesser incentive to pursue a greater recovery.

We believe that Baker, Perino, \& Silver's concerns are overstated. Although lead counsel has to weigh the risks of pursuing the litigation in hopes of greater recovery, if the lead plaintiff has negotiated for break points in the fee agreement, they are clearly sophisticated enough to understand the incentive effects created by those break points. It is for the lead plaintiff to decide whether to accept or reject any offer of settlement, and they will make that decision knowing that the court will be reviewing the decision to accept a settlement. If the court sees an early settlement of a case in the vicinity of a break-point, it will know to ask questions of the lead plaintiff about the decision to settle and whether it would be in the class's interest to pursue the litigation further.

If there is a strategic disadvantage to the lead plaintiff in negotiating a settlement from having disclosed break points in a fee agreement, it could be countered by the negotiating for a higher percentage above certain levels, signaling that counsel is strongly incentivized to pursue the largest possible recovery. And what stronger signal could a lawyer send about the strength of her case? If disclosure induced lawyers to negotiate for higher percentages for larger recoveries, it would have the fortunate collateral effect of targeting deterrence where it is most needed, that is, the most egregious cases of fraud. Maintaining the current secrecy around fee agreements gives cover to lawyers charging higher percentages in cases that are being brought purely for 


\section{Choi \& Pritchard, Lead Plaintiffs}

their extortion value, with no real prospect of prevailing at trial. More transparency would shed light on these speculative cases.

\section{B. Standing \& Fee Shifting}

Weiss and Beckerman, in their original proposal that would eventually be adopted by Congress as the lead plaintiff provision of the PSLRA, endorsed institutional involvement based on the perception that institutional investors held substantial stakes. Those stakes would give them appropriate incentives for them to monitor litigation decisions, and the sophistication that would enable them to do so effectively.

The PSLRA as adopted, however, does nothing to screen out investors who have not suffered substantial losses from serving as lead plaintiff. These "figurehead" plaintiffs are precisely the type of plaintiff that Congress hoped to displace with the PSLRA, and yet they persist in cases for which there is little or no competition for lead plaintiff status. They have little regard for whether the lawsuits that they lend their names to produce any benefit to the shareholder-members of the class. As discussed above, individual investors continue to serve as lead plaintiffs in a substantial portion of securities fraud class actions, and the results are not encouraging: high fee percentages to lawyers and minimal recoveries for investors.

Individual investors are not the only figurehead plaintiffs; institutional status can be a noisy proxy for having a substantial stake in the litigation. Many institutional lead plaintiffs, such as union and municipal pension funds, are quite small and have relatively minor stakes. Similarly, many smaller institutions lack any particular sophistication. These institutions should not be analyzed separately from individual lead plaintiffs with similar size stakes. We should not expect these institutions to add distinctive value to litigation. Supporting this idea, Baker, Perino, and Silver (2015) find that union pension funds agree to fee levels that are indistinguishable from fees agreed to by individual lead plaintiffs.

The fact of the matter is that many securities class actions are still brought with no expectation that the plaintiff would be able to prevail at trial, but rather, with the hope that the company's D\&O insurer will pay a nominal settlement to make the case go away. These cases do little for either compensation or deterrence. According to Cornerstone (2015), 26\% of securities fraud class actions settled for nuisance value-which Cornerstone defines as $\$ 2$ million-or less. That is an exceptionally conservative estimate of the cost of defending a securities fraud class action in an era with electronic discovery. A more realistic estimate of nuisance value would be at least $\$ 4$ million, at least for cases that get past a motion to dismiss. With the median settlement at $\$ 6.1$ million, it is possible that at least half of all securities fraud class actions are either being dismissed or settled to avoid nuisance costs. And given that Cornerstone reckons its median settlement number to reflect between 2 and $5 \%$ of shareholders estimated losses in these cases, it is difficult to argue that these settlements serve any compensatory purpose. The cost of D\&O insurance reflects this "fraud tax," which has little connection to the actual incidence of fraud. A portion of the plaintiffs' bar is able to make a living out of filing formulaic complaints in the wake of a stock price drop and collecting a modest toll from the insurance companies. In exchange, these plaintiffs' attorneys offer the preclusion of future claims. 
These depressing figures suggest that the screening that the PSRLA imposes on securities fraud complaints does not adequately weed out many of the cases that are lacking in merit. It is implausible that any competent lawyer would settle a securities fraud class action with any nontrivial prospect of recovery for less than $\$ 6$ million, even against an insolvent defendant. (There is always the D\&O policy limit to tap.) Many cases are being settled to avoid the expense of discovery and defense side attorneys' fees. These cases offer little in either compensation or deterrence, i.e., they are simply a wealth transfer to lawyers. If they could be screened from our system of litigation at a reasonable cost, shareholders of public companies would be unambiguously better off.

How can we get rid of these nuisance suits, short of adopting a pleading standard so stringent that it excludes substantial numbers of meritorious cases? The experiment with the lead plaintiff provision lights the path. Congress could amend the PSLRA to require a reasonable minimum loss - "skin in the game" - to serve as lead plaintiff.25 The evidence surveyed above shows that plaintiffs with skin in the game: 1) screen for good cases; and 2) produce better results. Why not harness this expertise to make securities fraud class actions more efficient at deterring fraud? There is no more direct way of ensuring sufficient incentive to promote the interests of the class as a whole than requiring that the lead plaintiff have a substantial loss from the alleged fraud. Under this proposal, those incentives would be tapped to ensure that lead plaintiffs were bringing cases that should be brought.

Picking the appropriate number of loss for eligibility to serve as lead plaintiff is an imprecise task, but it seems obvious that the correct number has to be more than $\$ 800$, the smallest number reported by Choi (2011). There may be individuals and small institutions with sufficient losses to encourage them to be an active monitor. It is hard to imagine, however, that the number required to provided sufficient incentive is zero. Obviously, imposing a minimum loss requirement would mean that some cases would not be brought. That is the point. If a plaintiffs' lawyer cannot persuade even a single shareholder with more than nominal losses to file suit, why should a court spend valuable judicial time resolving it? And, why should a defendant bear the expense of litigating the action?

The challenge in setting a standing requirement is that there is unlikely to be a clear dividing line between investors with large and small losses in terms of the results that their lawsuits produce. Choi (2011) reports a median loss among lead plaintiffs in settled cases of $\$ 286,000 ;$ but $\$ 237,000$ for cases that did not result in a settlement. Given that many of settlements were for nominal amounts, this finding may overstate the similarity between the two groups. A more refined distinction would include nominal settlements among the cases that are not cost justified. The table below shows the proportion of cases that can be classified as nuisance suits in the sample

\footnotetext{
25 Legislation would likely be required to implement the proposal outlined here as the SEC would be likely to view any attempt by a company to adopt the proposal through a charter amendment as inconsistent with the federal securities laws. (Sjostrom, 2015; Coffee, 2015)). Fee-shifting is prohibited by Delaware corporate law, Del. G.C.L. $\S \S 102(f), 109$ (b), but the prohibition likely does not apply to federal securities claims. (Bainbridge, 2016). Imposing liability on lawyers for fee-shifting, however, would probably require the preemption of state ethics rules. Model Rules of Professional Conduct, Rule 1.8(e) (forbidding lawyers, with certain exceptions, from providing "financial assistance to a client in connection with pending or contemplated litigation").
} 


\section{Choi \& Pritchard, Lead Plaintiffs}

relied upon in Choi (2011), broken down by provable losses alleged by the lead plaintiff arranged from bottom decile to top decile of losses. We define nuisance suits as cases that were dismissed on a motion to dismiss or summary judgment, or that settled for less than \$4 million, a conservative estimate of defense costs.

\begin{tabular}{|l|l|l|}
\hline Decile & \% Nuisance & Mean Provable Loss \\
\hline 1 & $84.8 \%$ & $\$ 9,178$ \\
\hline 2 & $57.6 \%$ & $\$ 38,085$ \\
\hline 3 & $65.6 \%$ & $\$ 78,386$ \\
\hline 4 & $69.7 \%$ & $\$ 128,892$ \\
\hline 5 & $68.8 \%$ & $\$ 213,858$ \\
\hline 6 & $66.7 \%$ & $\$ 321,409$ \\
\hline 7 & $60.6 \%$ & $\$ 474,001$ \\
\hline 8 & $62.5 \%$ & $\$ 799,275$ \\
\hline 9 & $42.4 \%$ & $\$ 1,655,121$ \\
\hline 10 & $53.1 \%$ & $\$ 20,987,050$ \\
\hline
\end{tabular}

A robust standing requirement would set the standing cut-off at $\$ 1$ million in provable losses, the range at which the proportion of losing cases drops below half. Clearly plaintiffs with losses in this range have real incentive to monitor the litigation. Setting the standing requirement this high, however, would weed out more than $80 \%$ of the existing pool of lead plaintiffs, which could impair the deterrent value of securities fraud class actions. At the opposite extreme, setting the standing requirement at a nominal level- $\$ 10,000$ of provable losses-would weed out lead plaintiffs who are overwhelmingly bringing nuisance cases: nearly $85 \%$ in this sample. It is hard to imagine that screening these cases would have any significant impact on deterrence. (If anything, eliminating these cases would mean the remaining pool of filings would carry a stronger signal that wrongdoing was being identified, as there would be less dilution.) This would be a very lenient restriction on shareholder standing.26 Investors with this level of loss have a sufficient amount at stake to provide at least some assurance that shareholder-members of the class would think that this is a case that should be brought.27

An intermediate alternative would couple a slightly more robust standing requirement-perhaps $\$ 50,000$ or $\$ 100,000$ of provable losses - with a fee-shifting provision for cases brought by plaintiffs meeting that threshold, but with less than $\$ 1,000,000$ in provable losses. For lead plaintiffs with losses in the intermediate range, fees would be imposed on plaintiffs' attorneys if their cases were dismissed on a motion to dismiss or summary judgement, and awarded to them if they prevailed on summary judgment or at trial. (It would serve little purpose to impose the fees directly on these nominal plaintiffs, as many of them will be judgment proof, and most of them have little capacity to assess the likelihood that a case is a meritorious one.) A fee-shifting provision for nominal plaintiffs would give defendants an incentive to vigorously resist these

${ }_{26}$ Obviously, for a standing requirement to have its intended effect, there could not be grouping of losses among plaintiffs.

${ }_{27}$ Shareholders who could not meet this requirement could still be members of the class; they would just be ineligible to serve as lead plaintiff. 
cases if they are lacking in merit, as it appears that many are, and to settle early in cases with merit. At the same time, a plaintiffs' attorney who genuinely believes they have a strong case (if not a strong plaintiff), should not be dissuaded from bringing suit by the risk of a fee award. If they prevail, they get an additional award of fees. Even if they lose at trial, they would not be on the hook for the defendant's fees. Enhancing the lead plaintiff provision in this fashion would harness the incentives of plaintiffs' lawyers to screen out the weakest cases.

\section{Conclusion}

The law expects representative plaintiffs to serve a gatekeeping function in entrepreneurial litigation, yet currently does little to ensure that plaintiffs meet this expectation. If most plaintiffs in shareholder suits are non-lawyers with a minimal financial stake in the litigation, they cannot serve as a line of defense against frivolous lawsuits. Yet, the legal system anticipates that law firms will have to justify their litigation decisions to independent shareholders who have agreed to represent the interests of the shareholder class. Shareholders with little at stake, or who have been bribed to serve as shareholder, have little incentive to perform this monitoring function. In short, the prevalence of conflicted plaintiffs means that there is a missing monitor in many shareholder lawsuits, which in turn may help explain why plaintiffs' lawyers are able to file so many lawsuits that are dismissed or settled for nuisance value. Either way, they are imposing a cost on the system and ultimately, shareholders, who are its intended beneficiaries.

The legal system must do more to encourage plaintiffs to monitor their lawyers in securities class actions. Transparency and a minimum loss requirement, coupled with a fee shifting requirement for lawyers who are only able to recruit nominal plaintiffs, would go a long way toward promoting more effective monitoring. Shareholder litigation is uniquely suited for the reforms proposed here because many shareholders have the financial stake necessary to take an active role in litigation. Too many lawsuits remain in the hands of plaintiffs' attorneys, ultimately hurting corporations and their shareholders when they bring non-meritorious actions. The reforms proposed here would be an important step to ensure lead plaintiffs' interests are aligned with their fellow shareholders. 
Pritchard and Choi:

\section{Choi \& Pritchard, Lead Plaintiffs}

\section{References}

Bainbridge, Stephen M. 2016. “Fee-Shifting: Delaware's Self-Inflicted Wound," 40 Delaware J. of Corporate Law 851.

Baker, Lynn A., Michael A. Perino, and Charles Silver. 2015. "Is the Price Right? An Empirical Study of Fee-Setting in Securities Class Actions," 115 Columbia Law Review 1371.

Barrett, William P. (Oct. 11, 1993). “I Have No Clients," Forbes 52.

Cheng, C. S. Agnes, Henry H. Huang, Yinghua Li, \& Gerald Lobo, 2010. "Institutional Monitoring Through Shareholder Litigation," 95 J. of Financial Economics 356.

Choi, Stephen J. 2009. "Motions for Lead Plaintiff in Securities Class Actions," Journal of Legal Studies.

Choi, Stephen J. 2007. "Do the Merits Matter Less After the Private Securities Litigation Reform Act," 23 Journal of Law, Economics \& Organization 598.

Choi, Stephen J., Jill E. Fisch \& A.C. Pritchard. 2005. "Do Institutions Matter? The Impact of the Lead Plaintiff Provision of the Private Securities Litigation Reform Act," 83 Washington University Law Quarterly 869.

Coffee, Jr., John C., 1986. "Understanding the Plaintiff's Attorney: The Implications of Economic Theory for Private Enforcement of Law Through Class and Derivative Actions," 86 Columbia Law Review 669.

Coffee, John C., Jr. 2015. “'Loser Pays': The Latest Installment in the Battle-scarred, Cliff-Haning Survivial of the Rule 10b-5 Class Action," 68 S.M.U. 689.

Macey Jonathan R. \& Geoffrey P. Miller, 1991. "The Plaintiffs' Attorney's Role in Class Action and Derivative Litigation: Economic Analysis and Recommendations for Reform," 58 University Chicago Law Review 1.

Cox, James D. \& Randall S. Thomas. 2002. "Leaving Money on the Table: Do Institutional Investors Fail to File Claims in Securities Class Actions?" 80 Wash. U. L.Q. 855.

Cox, James D., Randall S. Thomas \& Lynn Bai. 2008. "There Are Plaintiffs and . . There Are Plaintiffs: An Empirical Analysis of Securities Class Action Settlements," 61 Vanderbilt Law Review 355.

Cox, James D. \& Randall S. Thomas with Dana Kiku. 2006. "Does the Plaintiff Matter? An Empirical Analysis of Lead Plaintiffs in Securities Class Actions," 106 Columbia Law Review 1587. 
Dewan, Shaila K. 2002. "Donors to McCall Profit in Cases State Pursues Against Corporate Wrongdoers," New York Times, Aug. 14, 2002, at B4.

Eisenberg, Theodore \& Geoffrey P. Miller. 2004. "Attorney Fees in Class Action Settlements: An Empirical Study," Journal of Empirical Legal Studies 27.

Erickson, Jessica. (2015). The New Professional Plaintiffs in Shareholder Litigation, 65 Fla. L. Rev. 1075.

Fisch, Jill E. (2001). Aggregation, Auctions and Other Developments in the Selection of Lead Counsel under the PSLRA, 64 CONTEMP. PROBS. 53.

Fisher, Daniel. 2006. "Securities Lawyer Bill Lerach Crusades for Corporate Justice. But What About the Shady Records of his Union Allies?," Forbes, Feb. 13, 2006, at 102.

Grundfest, Joseph A. 1995. “Why Disimply?,” 108 Harvard Law Review 727.

H.R. Rep. No. 104-369, 104th Cong., 1st Sess. (1995).

Johnson, M. F., K. K. Nelson \& A. C. Pritchard. 2007. “Do the Merits Matter More? The Impact of the Private Securities Litigation Reform Act," 23 Journal of Law, Economics \& Organization 627.

Johnson-Skinner, Drew T. 2009. "Paying to Play in Securities Class Actions: A Look at Lawyers' Campaign Contributions," 84 New York University Law Review 1725.

Perino, Michael A. 2008. "The Milberg Weiss Prosecution: No Harm, No Foul?," 11 Briefly . . , , American Enterprise Institute Monograph.

Perino, Michael A. 2012. "Institutional Activism Through Litigation: An Empirical Analysis of Public Pension Fund Participation in Securities Class Actions," 9 Journal of Empirical Legal Studies 368.

PricewaterhouseCoopers LLP, 2003. Securities litigation study, available at http://www.10b5.com/2003_study.pdf.

Private Securities Litigation Reform Act, 109 Stat. 737 (1995) (codified as amended in scattered sections of 15 U.S.C.).

Saparoff, Peter M., ay 10, 1996. "The Private Securities Litigation Reform Act of 1995: Illusion or Reality," SA90 ALI-ABA 505.

Securities and Exchange Commission, Office of the General Counsel, 1997. "Report to the President and Congress on the First Year of Practice Under the Private Securities Litigation Reform Act of 1995." 


\section{Choi \& Pritchard, Lead Plaintiffs}

Selvin, Milly. 2008. "Plaintiff-for-hire Sentenced: A Retired Lawyer Gets Home Detention in the Milberg Weiss Case," Los Angeles Times, Jan. 29, 2008.

Simmons, Laura E. and Ellen M. Ryan, 2003. "Post-Reform Act Securities Lawsuits: Settlements Reported Through December 2003," Cornerstone Research, available at http:// securities.stanford.edu/

Sjostrom, William K. (2015). "The Intersection of Fee-Shifting Bylaws and Securities Fraud Litigation," 93 Washington University Law Review 379.

Webber, David H. 2010. "Is "Pay-To-Play" Driving Public Pension Fund Activism in Securities Litigation?" 90 Boston University Law Review 2032.

Weiss, Elliott J., \& John S. Beckerman. 1995. "Let the Money Do the Monitoring: How Institutional Investors Can Reduce Agency Costs in Securities Class Actions," 104 Yale Law Journal 2053.

Weinberg, Neil, \& Daniel Fisher. 2004. "The Class Action Industrial Complex," Forbes, Sept. 20, 2004. 